\title{
Learning the Adoption of Mushroom Farming Partnership: A Case Study of Farmers and an Enterprise from Cianjur District, West Java, Indonesia
}

\author{
Rendi Febrianda ${ }^{1,3}$, Hiromi Tokuda ${ }^{2}$ \\ ${ }^{1}$ Graduated School of Bioresources, Bioresources Faculty, Mie University, Tsu City, Mie Prefecture, Japan \\ ${ }^{2}$ Bioresources Faculty, Mie University, Tsu City, Mie Prefecture, Japan \\ ${ }^{3}$ Pappiptek - LIPI, Jakarta, Indonesia \\ Correspondence: Rendi Febrianda, Graduated School of Bioresources, Bioresources Faculty, Mie University, Tsu City, \\ Mie Prefecture, Japan.
}

Received: May 8, 2018

Accepted: June 2, 2018

Available online: June 22, 2018

doi:10.11114/ijsss.v6i7.3263

URL: https://doi.org/10.11114/ijsss.v6i7.3263

\begin{abstract}
Mushroom farming is one of the profitable agribusiness especially for rural areas in developing countries. It can be adopted and applied as a sideline or main business. Through a partnership, farmers are indeed able to resolve their falter caused by production problems and market challenges. However, some questions emerge about the effectiveness of partnerships. Learning the adoption of the partnership specifically on mushroom farming can provide more understanding about its strengths and its weaknesses for further better use. This study aims to review the adoption process and the experience of an informal partnership case between a mushroom enterprise and farmers using qualitative and non-parametric quantitative approaches framed by Rogers's innovation-decision process. The result shows that the partnership delivers ample benefits for the farmers and is recommended especially for rural society in certain conditions, though before and after the implementation, some issues were found, and suggestions are given for improvement.
\end{abstract}

Keywords: mushroom farming, partnership, innovation, rural society

\section{Introduction}

Edible mushrooms have been extensively consumed as nutritious foods which have a healthy impact on the human body (Cheung, 2010; Feeney, 2011). Edible mushrooms are valued for their high-quality protein, excellent unsaturated fatty acids, and high content of some vitamins. They are considered as low calorie foods, have anti-cancer properties, and are linked to the current concept of healthy diet (Kaldis \& Kontogeorgakos, 2002; Marshall, 2009). These facts help to promote mushroom consumption over the world. Food and Agriculture Organization of the United Nations (FAO) confirmed that the world mushroom production reached above 10 billion $\mathrm{kg}$ in 2014 and $70.6 \%$ of that production is shared in Asia.

Mushroom farming can become a propitious business and an attractive activity, especially for rural society as mushroom farming requires access to unspecific land and only a slight capital needed (Barmon et al., 2012). Mushroom farming has a great allure as it also does not depend on external climatic conditions, it possesses short growing times and easy use of technology. Economically, it can reduce poverty and strengthen the livelihoods through a quick yielding and a reliable source of income (Lelley, 1988; Marshall, 2009; Zhang et al., 2014).

Despite mushroom farming is considered as an attractive agribusiness, the development seems stagnant and even in decline recently including in Indonesia (see Table 1). The world mushroom production was annually increased as it is influenced largely by China's domination. Japan, as a developed country, was successful on mushroom farming. However, because of high labor cost, it was difficult for Japan to compete with China. On the contrary, other countries such as Indonesia, India, and Vietnam have a great potential for mushroom farming (Zhang et al., 2014).

In Indonesia, referring to the statistical report of the national production of horticulture issued by the central government of Indonesia in 2014, mushroom production had reached 37,410 tonnes. Based on the report, among the 25 vegetable commodities, mushroom commodity ranked $22^{\text {nd }}$ and contributed $0.31 \%$ over all production of the commodities (Dirjen 
Hortikultura Kementerian Pertanian, 2015). Nevertheless, developing countries like Indonesia have advantages for mushroom cultivation. FAO has been actively promoting mushroom cultivation for the rural development and food security of developing countries (Marshall, 2009). In addition to plentiful laborers, Indonesia is one of the potential developing countries that deliver abundant quantities of organic wastes from forestry and agricultural sector. Since mushroom cultivation uses a medium made from organic waste as the growing medium for mushroom seeds, it becomes one of an effective recycling method that can perform an important role in managing and utilizing waste problem into valuable resources (Beetz \& Greer, 1999; Youri et al., 2004). Furthermore, Indonesian practitioners such as farmers and sellers in the market also claimed often that the local demand of Indonesian mushroom market have evolved higher than the supply, and not only higher productivity but also a higher quantity of mushroom farmers will be needed to fulfill the demand. The consumption data may slightly represent the growth of the local demand and support this claim (see Table 1).

By the assumption of its strength and opportunity, mushroom farming is certainly worthy to be promoted especially for rural society in Indonesia. Nonetheless, one of the main issues in the development of Indonesian mushroom commodity is that still the low interest of the society on the adoption of mushroom farming.

Table 1. The development of mushroom total production and consumption in Indonesia

\begin{tabular}{ccc}
\hline Year & Production $(000 \mathrm{Kg})$ & Consumption $(\mathrm{Kg} / \mathrm{Capita} /$ Year $)$ \\
\hline 2010 & 61,000 & - \\
2011 & 45,854 & 0.057 \\
2012 & 40,886 & 0.057 \\
2013 & 44,565 & 0.057 \\
2014 & 37,410 & 0.087 \\
Average growth $(\%)$ & -10.64 & 17.54 \\
\hline
\end{tabular}

Source : The statistical report of Ministry of Agriculture of Indonesia (Dirjen Hortikultura Kementerian Pertanian, 2015)

A previous study identified specifically such aspects as the inadequate support for production and the deficient market support as the obstacles on the dissemination and adoption effort of mushroom farming (Pradhan \& Nayak, 2014). We found and suggested that a partnership between enterprise and rural society is an alternative strategy to overcome those obstacles as enterprise has both the technical capabilities and market access (Febrianda \& Tokuda, 2017). Partnership can assist farmers in applying good agricultural standards and production as well as reduce the constraints in accessing the markets (Bitzer et al., 2013; Dentoni et al., 2016; Royer et al., 2017). Innovative partnerships that pool together businesses, governments, and society are being increasingly promoted as having the potential to deliver multiple benefits for small farmers while mitigating some of the risks in order to contribute on the sustainable agricultural development (FAO, 2016). However, Rogers indicates that having a new idea adopted, even if it has obvious advantages, is often very difficult (Rogers, 2003). FAO also noted that some unanswered questions emerge about the effectiveness of partnerships depending on their implementation (FAO, 2016). FAO itself has published a review of the international experiences on partnerships to improve the understanding of their benefits and challenges, but none comes from the mushroom commodity yet.

A mushroom enterprise which has implemented a partnership with farmers has been found, some challenges may appear and the farmers' responses (current adopters of the partnership) are also needed for reviewing the effectiveness of the partnership, and supporting the consideration of the partnership as an alternative strategy. Learning the adoption of this partnership can offer more understanding in promoting it further. Adoption is a process from first hearing it until finally adopting it (Rogers, 2003). This study aims to review the experience on the adoption case of mushroom farming partnership into ongoing practice. The focus is on a case between one enterprise and its partners from Cianjur district of West Java province, Indonesia. The species of Pleurotus ostreatus (oyster mushroom) is selected as one of the three major species in the world (Lahman \& Rinker, 2002) and mostly dominates the mushroom markets in Indonesia.

\section{Mushroom Farming Development and Mushroom Farming Partnership at Glance}

In 1980, mushroom farming expanded by using an artificial medium instead of a natural medium which was primarily composed of sawdust. The new medium will be able to produce three to four times as many fresh yields of mushroom compared to the natural medium, in a shorter time. The cultivation also can be moved inside buildings, which permits manipulations of temperature, humidity, and light to improve yield. This grass-roots level of innovation has a particular role in the development of mushroom farming (Zhang et al., 2014).

Oyster mushroom farming in Indonesia is estimated starting in 1988 or 1990. Thereafter, many practical improvements have been performed. For example, we have shown the local champion of mushroom enterprise from Cianjur district which has successfully introduced innovations. This enterprise not only improves the reliability of its artificial medium technology but also implements a partnership to expand its business and to empower the local society (Febrianda \& Tokuda, 2017). 


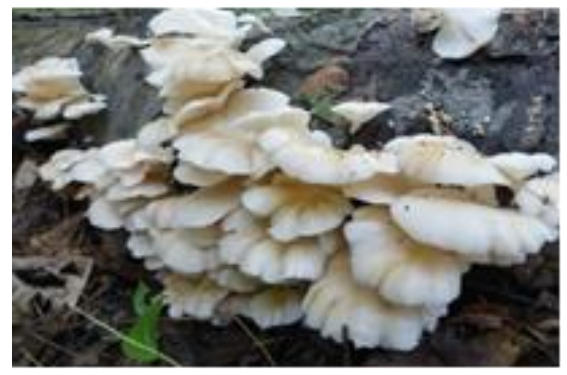

(a)

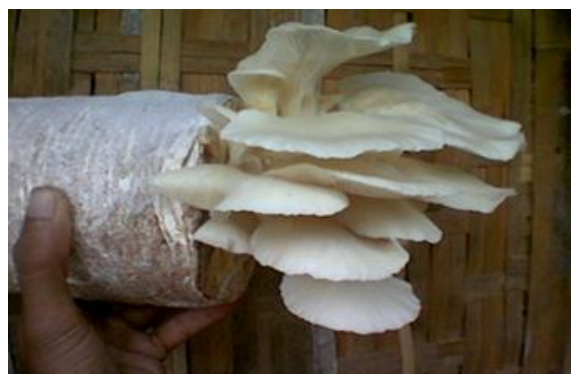

(b)

Figure 1. The oyster mushroom growing on a trunk/natural medium (a) and on an artificial medium (b)

Source of image (a): http://www.ediblewildfood.com/oyster-mushroom.aspx.

West Java province occupied the first rank of mushroom production with a total production of $25,194,471 \mathrm{~kg}$ or about $67 \%$ of national mushroom production in 2014 (Badan Pusat Statistik Kabupaten Cianjur, 2015). Cianjur, a well-known district in West Java, is considered as one of the central areas for mushroom production in which $62.99 \%$ of the population are employed in the agricultural sector (BPS Kabupaten Cianjur, 2017).

Mushroom farmers used to have the capability of making an artificial medium (baglog) for mushroom and then do the cultivation, but now the farming could be started simply from cultivation. Even without experience, people can join the farming through a partnership. Partnership is defined as collaborative arrangements between actors of society such as the agricultural enterprise and farmers. It is used to address rural development challenges such as market access for small farmers (Kolk et al., 2008). Partnership for agribusiness can be defined similarly to contract farming as a commercial relationship between an enterprise and a group of farmers and is considered to be a positive development in agricultural innovation in developing countries (FAO, 2013). In Indonesia, partnerships are popularly implemented by palm oil plantations among public and private partners. Indonesian government has issued regulation No. 44 in 1997 which states that a partnership is a cooperation between small businesses with the principle of mutual need, mutual strengthening, and mutual benefit. Thereafter, similar partnerships are adopted and implemented by various private sector especially between an enterprise and farmers. FAO noted that the recent application of the partnership in the development of society has been slightly broader, involving both formal and informal parties such as public sector, private sector, non-governmental, and civil society organizations (FAO, 2016).

AAC is known as one of the champions from Cugenang sub-district of Cianjur district, which implements a partnership successfully with farmers. This sub-district shares $73.5 \%$ of Cianjur district mushroom production (BPS Kabupaten Cianjur, 2017). AAC was established in 2003 and performs as a producer of mushroom artificial medium/baglog, as a farmer/cultivator, as a provider of mushroom farming tools and equipment, and as a trainer of mushroom technology. In 2004, the enterprise dealt with their limitation to fulfill its demand from the local market of Cianjur district. In addition to complying with the demand, it offered a partnership to empower the local society of Cugenang sub-district. The mechanism of the partnership involves such points as those given in Table 2.

Table 2. Mechanism of the mushroom farming partnership

\begin{tabular}{lll}
\hline Enterprise & \multicolumn{2}{l}{ Farmer } \\
\hline 1) & produces baglogs for farmers & 1) baglogs will be paid in full \\
2) training of cultivation techniques & 2) commitment to the training \\
3) provides technical services & 3) provides space and capital for infrastructures \\
4) assists cultivation control & 4) performs the cultivation \\
5) provides market support & 5) sells the yields (fresh mushroom) to enterprise \\
& & based on the agreement of selling price
\end{tabular}

\section{Analytical Approach and Method}

An innovation is the introduction of something new like an idea, method, or so forth (Merriam-webster.com). Rogers's theory of diffusion of innovation has been successfully used in many fields, especially in the cases of agricultural products, technology, and services. Rogers argued that any idea, practice, or object that is perceived as new by an individual or other unit of adoption could be considered an innovation available for study. Rogers described the innovation-decision process as "an information-seeking and information-processing activity, where an individual is motivated to reduce uncertainty about the advantages and disadvantages of an innovation". "An innovation may have been invented a long time ago, but if individuals perceive it as new, then it may still be an innovation for them". The innovation-decision process covers five steps: (1) knowledge, (2) persuasion, (3) decision, (4) implementation, and (5) confirmation. 
1) Knowledge - the individual is exposed to the existence of the innovation and gains some understanding of how it functions.

2) Persuasion - the individual will form a favorable or unfavorable attitude towards the innovation.

3) Decision - the individual chooses to adopt or reject the innovation.

4) Implementation - the individual puts an innovation into use.

5) Confirmation - the individual tries to verify the decision already made, or reverse this decision if exposed to conflicting messages about it.

Rogers also defined the adopter categories (Table 3) as the classifications of adopters in a social system on the basis of their innovativeness. Innovativeness is defined as "the degree to which an individual or other unit of adoption is relatively earlier in adopting new ideas than other members of a system". These categories are influenced by adopter characteristics such as the education level, the length of decision, wealth and so on.

This study is a single case study and the data are collected in 2017 by interview. The targeted adopters of the mushroom farming partnership were 30 mushroom farmers incorporated with the AAC enterprise. The interview guidelines were built upon the framework of the innovation-decision process from Rogers's theory. The analysis of this study is performed using both qualitative and quantitative approach. The idea of this study is divided into 3 points:

- to operate the classification of adopters which refers to the requisites on Table 3 . The adopter characteristics such as the education level, the source of knowledge, the length of decision, and the farming scale of the adopters were examined and analyzed quantitatively using nonparametric correlation to determine whether these variables relate with the classifications (groups) of adopters.

- $\quad$ to understand their experience in the five phases of the adoption process. The data relating to the experience of the adopters are presented and analyzed qualitatively using the framework.

- the notable points of the result will be discussed with the related reports, articles, and expert opinions for developing suggestions.

Table 3. The classification of the adopters

\begin{tabular}{|c|c|c|}
\hline Groups & & Requisites \\
\hline Earlier Adopters & Early Adopters & $\begin{array}{l}\text { - they also actively seek information about new ideas but are limited by the } \\
\text { boundaries of the social system } \\
\text { they hold leadership roles and serve as a role model for other members of a } \\
\text { social system } \\
\text { the same as early adopters but they seldom hold leadership or role model } \\
\text { statuses }\end{array}$ \\
\hline Later Adopters & Late Majority & $\begin{array}{l}\text { - economic necessity and peer pressure may lead them to the adoption of the } \\
\text { innovation }\end{array}$ \\
\hline
\end{tabular}

\section{Result and Discussion}

\subsection{Innovation-Decision Process}

\subsubsection{The Prior Conditions}

The earlier stage of the decision-making process of innovation is called the previous conditions before the adoption. In this stage, there are previous practices, perceived needs and problems, and innovativeness. The implementation of the innovation ends at the point at which the new idea becomes a regular choice, often referred to as routinization (Rogers, 2003). Currently, mushroom enterprises which implemented such mushroom farming partnership could be widely found, particularly in Cianjur district. It is assumed that this mushroom farming partnership is starting to become a common case within mushroom farming in this area so that there will be several categories of adopters from the respondents.

As shown in Figure 2, majority of the adopters' previous practices were farmer consisting of paddy farmers and fish farmers. The needs and problems were varied. For example, employees reported the same point specifically that they were searching for other simple jobs that could possibly be done as a side job for obtaining additional income. Some farmers also reported the same need while the rest of these farmers were undergoing a different situation. They reported that they had no such needs until they noticed the benefit of this partnership from their fellows which became the reason for their adoption. All these farmers responded that before adoption, their problems were associated with the difficulty and failure risk of their farming. For small entrepreneurs and part-time jobs, they seemed to make a similar decision from the beginning in seeking a business which did not require much capital. Despite departing from diverse problems, their needs were basically connected to an expectation of a simpler job that offered a more reliable source of income. 

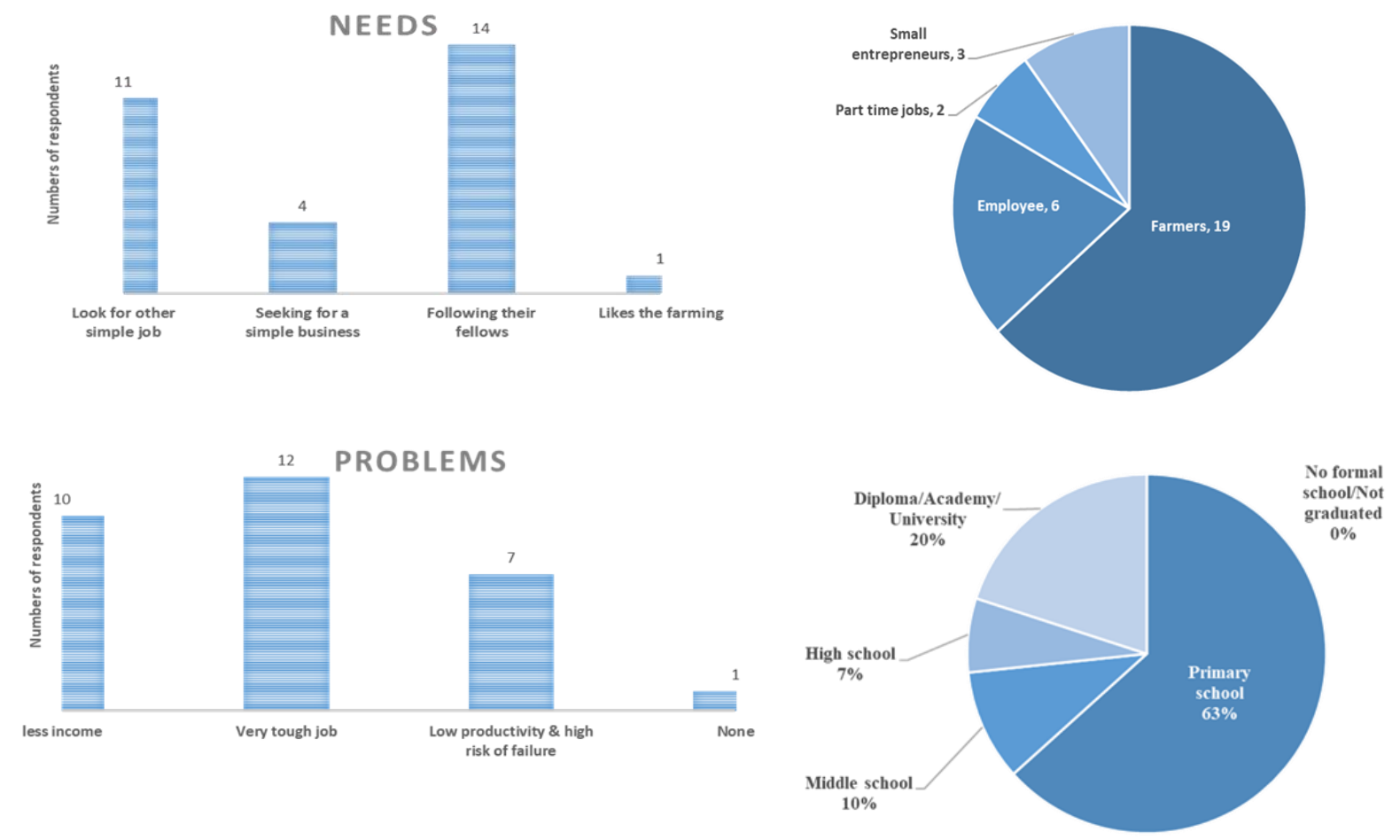

Figure 2. The background of the needs, problems, works, and educations

This study does not predict the degree of their innovativeness as the number of the adopters are limited. After all, their socio characteristics illustrate that most of them were productive workers (35-50 years old) with a low education level. Rogers stated that earlier adopters had more years of education than later adopters did. Then a partial nonparametric correlation was created to see whether their education had a positive impact on their groups in this partnership.

Table 4. The scores of the group, education level, and sources of knowledge

\begin{tabular}{cccccc}
\hline Groups & Score & Education Level & Score & Knowledge Source & Score \\
\hline Early adopters & 3 & Diploma/Academy/University & 5 & Enterprise & 2 \\
Early majority & 2 & High school & 4 & Associates & 1 \\
Late majority & 1 & Middle school & 3 & & \\
& & Primary school & 2 & & \\
& & No formal school / not graduated & 1 & & \\
\hline
\end{tabular}

The stipulation of the adopters into groups is classified qualitatively based on the requisites of table 3 . Generally, there are two main groups of them: earlier adopters (innovators, early adopters, and early majority) and later adopters (late majority and laggards). The key of difference between the earlier and later adopters is that the later adopters are the people adopting due to economic necessity or peer pressure.

Majority of the adopters who come into a partnership with AAC enterprise are earlier adopters. This occurred presumably due to this enterprise was being included as a pioneer in executing a partnership. The result of the correlation indicates that education has a positive relation to their groups (see Appendix). This result is in line with the previous results (Mahajan, 1990; Rogers, 2003) however there are low educated people who also quickly adopted into this partnership. 
Table 5. The attributes of the adopters

\begin{tabular}{|c|c|c|c|c|c|c|c|}
\hline Adopters & Education & $\begin{array}{c}\text { Knowledge } \\
\text { Source }\end{array}$ & $\begin{array}{l}\text { Knowledge } \\
\text { Exposed }\end{array}$ & Decision & $\begin{array}{c}\text { Starting } \\
\text { Scale } \\
\text { (baglogs) }\end{array}$ & $\begin{array}{c}\text { Maximum } \\
\text { Scale } \\
\text { (baglogs) }\end{array}$ & Groups \\
\hline 1 & 2 & 1 & 2005 & 2007 & 2500 & 30000 & 1 \\
\hline 2 & 5 & 2 & 2004 & 2004 & 5000 & 100000 & 3 \\
\hline 3 & 2 & 1 & 2007 & 2009 & 3000 & 40000 & 1 \\
\hline 4 & 2 & 1 & 2006 & 2009 & 3500 & 33500 & 1 \\
\hline 5 & 4 & 2 & 2004 & 2005 & 3000 & 35000 & 2 \\
\hline 6 & 5 & 1 & 2005 & 2006 & 4000 & 50000 & 2 \\
\hline 7 & 2 & 1 & 2006 & 2007 & 5000 & 45000 & 2 \\
\hline 8 & 2 & 2 & 2004 & 2008 & 2000 & 32000 & 1 \\
\hline 9 & 4 & 1 & 2005 & 2005 & 2500 & 38000 & 2 \\
\hline 10 & 3 & 2 & 2004 & 2006 & 4000 & 60000 & 2 \\
\hline 11 & 3 & 1 & 2006 & 2006 & 3500 & 40000 & 2 \\
\hline 12 & 5 & 2 & 2004 & 2005 & 4200 & 50000 & 2 \\
\hline 13 & 2 & 1 & 2006 & 2007 & 3000 & 33000 & 2 \\
\hline 14 & 2 & 1 & 2009 & 2011 & 2500 & 32500 & 1 \\
\hline 15 & 2 & 1 & 2009 & 2011 & 3300 & 53300 & 1 \\
\hline 16 & 5 & 2 & 2004 & 2006 & 4500 & 64500 & 2 \\
\hline 17 & 2 & 1 & 2009 & 2010 & 2500 & 30000 & 1 \\
\hline 18 & 2 & 1 & 2009 & 2010 & 2000 & 42000 & 1 \\
\hline 19 & 5 & 2 & 2004 & 2007 & 2000 & 32000 & 1 \\
\hline 20 & 2 & 1 & 2008 & 2009 & 4500 & 55000 & 1 \\
\hline 21 & 2 & 2 & 2004 & 2007 & 2300 & 32300 & 1 \\
\hline 22 & 2 & 1 & 2007 & 2008 & 3000 & 33000 & 2 \\
\hline 23 & 2 & 1 & 2007 & 2009 & 2800 & 33000 & 1 \\
\hline 24 & 2 & 1 & 2006 & 2007 & 4500 & 44500 & 2 \\
\hline 25 & 5 & 1 & 2007 & 2008 & 2500 & 35000 & 1 \\
\hline 26 & 2 & 1 & 2006 & 2007 & 4500 & 44500 & 2 \\
\hline 27 & 4 & 1 & 2005 & 2006 & 3000 & 33000 & 2 \\
\hline 28 & 5 & 2 & 2004 & 2005 & 6000 & 36000 & 2 \\
\hline 29 & 2 & 1 & 2008 & 2009 & 2300 & 35000 & 1 \\
\hline 30 & 2 & 2 & 2004 & 2005 & 2500 & 30000 & 2 \\
\hline
\end{tabular}

4.1.2 The Knowledge Stage

This stage aims to describe how the knowledge about the existence of the partnership occurred. "The knowledge stage occurs when the individual is exposed to the existence of the innovation and gains some understanding of how it works" (Rogers, 2003). The information of the mushroom farming partnership is dispersed in two ways: the enterprise's direct dissemination through a gathering event to communicate with the society and interpersonal communication of the society. The information was initially disseminated in early 2004 and only 10 of the adopters claimed to obtained the information directly from the enterprise. The rest of them reported that they obtained the information from their associates or through peer networks. Once an agricultural innovation reaches an individual farmer, horizontal transfer of the new idea passes through the peer networks among their relatives and fellow villagers so that this channel of social networks is also considered as playing a role at the early stage of dissemination (Rogers, 2003; Zhang et al., 2014). The correlation performed to find whether their source of knowledge was related to their groups shows a weak relation (see Appendix).

The enterprise was reportedly offering the type of farming that was easy for everyone, that was low risk, and quite profitable. It marketed a more reliable baglog technology for mushroom cultivation and it also offered a partnership which will grant assistance in aspects of production and marketing. The partnership was intended for those who had no experience of mushroom farming. Majority of the adopters reported that they were familiar with mushroom cultivation but none had knowledge and experience about the function of the partnership. In case of complex systems that require even greater knowledge, a greater tendency for rejection or discontinuation may occur (Rogers, 2003). However, all of them found no trouble in comprehending such a simple offer during the explanation as no specific skill or knowledge was needed. On the contrary, the function of the partnership is believed to be useful to reduce the risk and to attract the interest of the society in addition to the function of mushroom farming. In this stage, the following reasons were found as good reasons for the adopters to continue to the next stage:

- Mushroom farming is simple and has a low risk. The partnership can serve new users in helping them to solve the issues of the probability of production failure and market confusion.

- Some respondents revealed that the profit was reported also in this stage for about 20\%-22\% per baglog, while some of them gained this knowledge in the persuasion stage. 


\subsubsection{The Persuasion Stage}

In the persuasion stage, the adopters deepen their knowledge by seeking information about its advantages or disadvantages and form a favorable or unfavorable attitude towards the mushroom farming partnership. The main source of this stage is the enterprise and it was reportedly available for all candidates or even anyone who needs to make a meeting or discussion regarding the partnership. In this stage, there are also auxiliary sources which were the earlier adopters. These sources helped in providing detailed information about the partnership to their associates, especially to the later adopters.

In the persuasion stage, Rogers designates an attribute which is called the relative advantage of the new idea. This is the characteristic to which an innovation is perceived better than the idea it replaces. The idea that it replaces is that mushroom farming in which case a farmer must have both the ability to make an artificial medium technology (baglog) before doing the cultivation and possess market access as well. Unfortunately for novices, this common idea takes a long time as it requires specific skills, effort, practice, and experience. All adopters reported the favorable points which were generally the same that the partnership was perceived as quite helpful as they did not need to bother thinking about skill and experience. Briefly, the enterprise made the farming sound simple. The unfavorable point of this partnership was reportedly the lack of support in accessing funding. Either the enterprise or the financial institutions were not found supporting the financial aspect. This meant that the candidates must have had to have enough financial capacity. Their understanding in this stage included the points below:

- The mechanism of the mushroom farming partnership.

- The enterprise provided feasibility analysis of the partnership. The profit could be predicted from the results of the analysis.

- There was no funding support. For the partnership, farmers are needed to have their own capital and space for farming. Fortunately, mushroom farming is flexible. It can use any available spaces, or, in other words, it does not require ground or a specific farmland. The farming layout can also be done vertically using shelves, resulting in excellent space efficiency.

\subsubsection{The Decision Stage}

In the decision stage, the adopters choose to adopt or to reject. In this study, there are no rejections as it is designed for the adopters and there is no discontinuance as all adopters are still active farmers.

In this stage, the adopters finally commit to the enterprise to get into the partnership. They reported that once they decided to join, they agreed to prepare space for farming and cash for each component of the baglogs, tools, and construction of the cultivation house. Some of them could erase the cost of the house by using their own resources. Since no supporting funding or credit provided, majority of the adopters claimed that they started with deposit money, while the rest obtained loans from their relatives. The main point as the background of their decision, both the earlier adopters and the later adopters claimed the same points: the easiness and low risk of performing the business. However, the triggers were different and divided into 4 categories (see Table 6). The earlier adopters decided to adopt due to their own understanding, attaining directly from the enterprise. While for the later adopters, the role of their peers who seemed successful influenced their decision and became the main trigger. In this case, there was one adopter who served frequently as a role model.

The stipulation of the adopters into groups is also influenced by the length of their decision in which earlier adopters had shorter innovation-decision periods (Rogers, 2003). The shortcoming is, the length of their decision is not detailed (months and days), as most of the adopters are not able to remember the details. Nonetheless, the result shows that the length of their decision relates to their groups negatively (see Appendix). This means that the lower the score of the groups (for example, later adopters) the longer the length of their decision than higher groups (for example, earlier adopters).

Table 6. The differences of the trigger and the process toward the decision stage

\begin{tabular}{|c|c|c|}
\hline Category & Trigger and Process & Group \\
\hline 1 & Knowledge from enterprise-continue to persuasion stage-trigger from enterprise-decision stage & $\begin{array}{c}\text { Earlier } \\
\text { adopters }\end{array}$ \\
\hline 2 & Knowledge from peers-continue to persuasion stage-trigger from enterprise-decision stage & $\begin{array}{l}\text { Earlier } \\
\text { adopters }\end{array}$ \\
\hline 3 & $\begin{array}{l}\text { Knowledge from enterprise-restraining for some time-trigger from previous adopters-continue to } \\
\text { persuasion stage-decision stage }\end{array}$ & $\begin{array}{l}\text { Later } \\
\text { adopters }\end{array}$ \\
\hline 4 & Knowledge from peers-trigger from previous adopters-continue to persuasion stage-decision stage & $\begin{array}{l}\text { Later } \\
\text { adopters }\end{array}$ \\
\hline
\end{tabular}




\subsubsection{The Implementation Stage}

This is the stage in which the adopters put the partnership into use. For the first time, this stage includes 4 steps: (1) construction of the cultivation house, (2) baglogs purchasing and distribution, (3) cultivation activity, and (4) marketing. Each baglog produces for one cycle (approximately 4 to 5 months) and the marketing will be picked up by the enterprise. Afterward, once the first cycle is finished, the stage will start again from the second step and so on.

The average starting scale of the adopters was 3330 baglogs/adopter and the average maximum scale is 41,736 baglogs/adopter. The problem which was found at this stage was also related to the lack of access to funding support. The adopters were supposed to be smart enough to set aside the returns for scale improvement. Earlier adopters were wealthier and had larger-sized units for farming (Mahajan, 1990; Rogers, 2003). The result of the correlation also supports the same argument in which the earlier adopters of the partnership tended to have bigger scale of the farming than later groups either at the starting scale or the maximum scale (see Appendix).

\subsubsection{The Confirmation Stage}

The confirmation step is taken as an evaluation of the positive and negative aspects of the adoption whether decide to continue or discontinue it. The claims reveal that the continuation of the partnership still serves a positive outcome, although there is still a hidden issue.

Based on the mechanism of the partnership, the yields of fresh mushroom from the adopters will be assigned to the enterprise based on the agreed selling price. The selling prices of the yields are reportedly monotonous as the enterprise concentrates only on conservative markets. The partnership does not ban the adopters from quitting, yet the farmers who possess a diverse market for obtaining a higher selling price must leave the status quo of the partnership. After all, this system was aimed initially for novices. The selling price of other mushroom farmers who are not incorporated with the partnership and pursue demands from supermarkets and central markets have the selling price twice to three times higher than the partnership farmers. AAC enterprise picks conservative markets because the payment process is instant so the cash flow becomes faster. This is a reasonable reason as the scale of its production is large already, however, the demands from different markets are also a profitable option. In this case, loss of after-sales services such as technical services which may be still needed and the reluctance to perform self-market distribution are the reason for quitting the partnership.

\subsection{Inputs for Improvement of the Partnership and the Adopters}

The adoption of agricultural innovations in developing countries generally deals with several constraints such as the lack of credit, limited access to information, reluctance to risk, inadequate incentives associated with human capability, and so on (Feder et al, 1985). In this partnership, three notable lessons are identified:

- In the knowledge stage, the information is diffused once and then continued by the interpersonal communication of society. Not the whole of the local society cognizes the information about the partnership. The information is estimated also to diffuse slowly and finds it difficult to reach outside the society.

- In the persuasion stage, a lack of access to funding support was found.

- In the confirmation stage, the selling price of the yields from the enterprise is monotonous. Some respondents claimed that they found other markets with higher selling prices, but they were sluggish to release the partnership.

The findings support previous notes which mention that general partnerships of agribusiness on fresh vegetables commodities have several constraints (Purnaningsih, 2006) such as (1) the information of the partnerships is not widespread and spread for only certain groups, (2) not all farmers have access to capital and they are reluctant to engage with bank credit, and (3) the price is determined by the partner enterprise. Therefore, suggestions are given both for further use of the partnership and for improvement of the adopters as described below:

- Mass media channels enable information to reach many audiences rapidly, create knowledge and spread information (Rogers, 2003). As enterprises have limited resources, cooperation with government or other private organizations' resources is a decent option to support the earlier stages through all possible channels such as mass media like television, radio, magazines, or agricultural extension service. The evidence in disparate area of Indonesia shows that the trend of mushroom farming is gradually increasing after it was pushed weekly by collaborated parties through an agricultural clinic program with the local television (Febrianda \& Laili, 2016). Nowadays, internet could be also an effective media for spreading information like a post on social media. In promotion, we should explore the use of alternative media such as the internet to get a wider audience (Duffy, 2000). Mushroom farming is convenient for both urban and rural areas, nevertheless, if it is disseminated in rural areas, not all rural society have access to mass media or internet especially in developing countries. Personal 
communications like extension services are still needed, at least when persuading or convincing and dealing with resistance (Altalb et al., 2015; Rogers, 2003). The extension service itself can deliver a knowledge about the information of the products or services (Anderson \& Feder, 2004).

- Rogers indicates that most change agents hope to speed up the process of the innovation-decision by communicating the information of new ideas more rapidly so that the knowledge is created at an earlier date which shortens the amount of time required for the innovation-decision (Rogers, 2003). Conversely, the people who most need the benefits of a new idea (such as the less educated people or poor people) are generally the last to adopt. The result of the correlation shows that only the education level and the source of knowledge variables are inter-correlated with each other while the education level itself is positively related to the group levels. It seems that the adopters who had an initial knowledge about the information of the partnership directly from the enterprise and then adopted it were the higher educated people. The focus of the early dissemination effort may be placed on the higher educated people while engaging these people as role models to obtain the interest of other less educated people.

- The farmers who are usually included in partnership or contract farming are rarely poor farmer (Ton et al., 2018). Government can specifically facilitate the development of partnership through direct incentives, for example, public funding conditional on private co-financing (OECD, 2014). By incorporating financial institutions into the partnership agreement and providing farmers with several incentives such as government guarantees, subsidized credit, and access to finance for small farmers, they will be able to afford the requirements of the investments in order to participate in the partnership (FAO, 2016). Incentives likewise have been paid in order to speed up the diffusion of innovations in a variety of fields (Rogers, 2003). In this partnership, most of the adopters were those who had adequate capital while the others were people who had to obtain loans from their relatives. Meanwhile, rural society mostly fears to engage with banking credit because of the complicated terms on credit proposal and their poor management. The allocation of the credit from the bank is low as well because of the viewpoint of the agricultural business as risky business (Ashari, 2009). Within the partnership, farmers will receive the management and production support that will minimize the risk, therefore, incentives or subsidized credit access may be needed so that the partnership can also be used to empower those who lack capital (underprivileged) but have good potency and interest.

- Transparency of the selling price of the yields has been maintained and is indeed necessary to protect the satisfaction of the adopters. However, there is no formal regulation yet which governs the selling price of mushroom commodity. Therefore, the price will refer to the market destination (conservative markets/supermarkets/central markets). In such formal partnership as in palm oil plantations of Indonesia, the selling price must follow the regularity from government. In this case, the selling price of the yields has been set by the enterprise and the market destination is the preference of the enterprise. The adopters who intend to pursue more profitable markets may leave the partnership and prepare for self-market distribution. Either intermediate farmers or producers are the good progress for the adopters of the partnership toward their future development (see Figure 3). Farmers can allocate mushroom farming as a side business as it is efficient in terms of time, land or space, and capital. However, if the farmers wish for the maximum result, they should focus by increasing the scale of the farming or develop the capacity by changing from a farmer who only cultivate to become a producer who produce the baglog as well (Wayan et al., 2015). Basically, mushroom farming is simple and less risky. The main key to this type of farming is the reliability of an artificial medium (baglog) in producing high-quality yields. By purchasing baglog from credible producers, mushroom farmers may focus in marketing the yields. However, for beginners, the partnership is the safest option. 


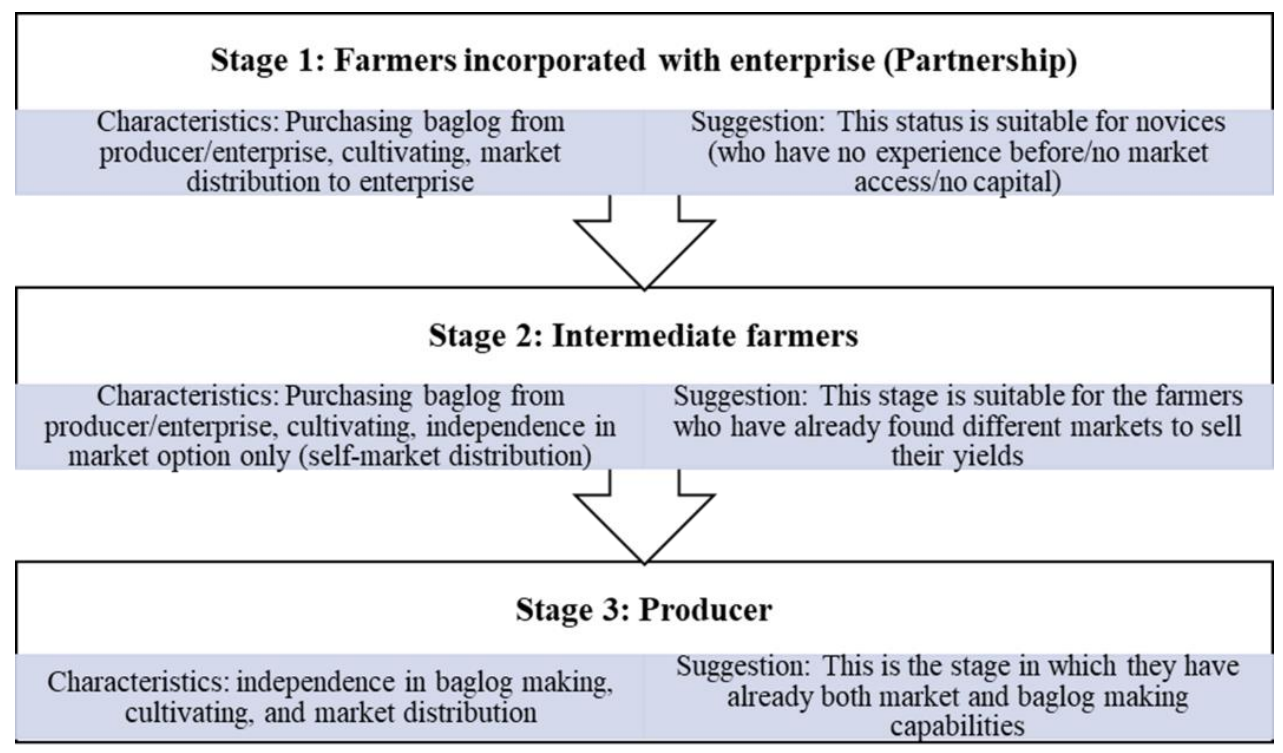

Figure 3. The decision options for mushroom farming

Table 7. The given points for the improvement of the partnership and the adopters

\begin{tabular}{|c|c|c|c|c|}
\hline Stage & Enterprise & Farmers & Government/Mass Media & $\begin{array}{l}\text { Banking } \\
\text { Services }\end{array}$ \\
\hline Knowledge & $\begin{array}{l}\text { Cooperation with local } \\
\text { government and other } \\
\text { parties to reach more } \\
\text { potential adopters }\end{array}$ & - & $\begin{array}{l}\text { Dissemination through extension } \\
\text { programs or mass media or internet }\end{array}$ & - \\
\hline Persuasion & - & - & $\begin{array}{c}\text { Facilitates access to loans or credit } \\
\text { subsidies }\end{array}$ & - \\
\hline Decision & - & - & - & $\begin{array}{l}\text { Provides } \\
\text { simple credit } \\
\text { access with } \\
\text { low interest }\end{array}$ \\
\hline Implementation & $\begin{array}{l}\text { Provides and encourages } \\
\text { baglog making training }\end{array}$ & $\begin{array}{l}\text { Not only the scale but also } \\
\text { focus on the skill and } \\
\text { capability improvement in } \\
\text { order to become a producer }\end{array}$ & $\begin{array}{l}\text { Encourages farmers to improve their } \\
\text { capability and facilitates access to } \\
\text { loans or credit subsidies for scale } \\
\text { improvement }\end{array}$ & $\begin{array}{l}\text { Provides } \\
\text { simple credit } \\
\text { access with } \\
\text { low interest }\end{array}$ \\
\hline Confirmation & - & $\begin{array}{l}\text { Prepare for taking on another } \\
\text { diverse market to obtain } \\
\text { more profit as an } \\
\text { intermediate farmer or } \\
\text { producer }\end{array}$ & - & - \\
\hline
\end{tabular}

\section{Conclusions}

A total of $63 \%$ of the adopters of AAC's partnership are low educated people. Meanwhile, $57 \%$ of the adopters are in the early majority group. Partial correlation results show that the education level, length of the decision, and the scale of farming have positive relations with the adopters group levels (categories) except for the source of knowledge. The earlier adopters who have adopted this partnership more quickly tend to have higher education levels, shorter lengths of the decision, and bigger scales of farming.

The result of the innovation-decision process shows that most of the adopters' problem was associated with their heavy work and they expected for simpler work. The result also shows that mushroom farming is simple and less risky business, and the mushroom farming partnership affords to counter the probability of production failure and market confusion for novices which means giving a more reliable source of income. The simplicity on performing the farming become the reason why this partnership could also be afforded and adopted quickly by few low educated people.

This partnership is truly recommended especially for rural society in three conditions. First, at least have sufficient capital for the farming. Second, they must be novices who have no experience before and no market access. The third is that there must be no objection to the set price of the yields. Unlike formal partnerships, this informal partnership possesses several 
limitations. From this experience, several notes are built to improve the use of similar partnership and the future development of the adopters such as

1) Enterprise should cooperate with other parties on dissemination through extension programs, mass media or internet to reach a wider society

2) The focus of the early dissemination effort may be focused on higher educated people while engaging these people as role models to obtain the interest of less educated people

3) To speed up the process of the innovation-decision, the effort may be focused likewise on wealthier people

4) Government and banking services could also cooperate in facilitating incentives and subsidized farm credit access to the partnership

5) Previous models still show the best system for achieving maximum business development. After some period of implementation, the adopters may be encouraged to improve their capability not only as a cultivator but also as a producer because the baglog (artificial medium technology) is the main key of the business development. To get a more profit, the adopters may exit the partnership as an intermediate farmer and move to other profitable markets. However, as a producer, they can be independence both in production and in the market.

This study only focusses on a single case study from one enterprise and its adopters. Thus, it can be improved by further studies involving a broader scope by involving other similar enterprises and their adopters to gain more comprehensive experience in the implementation of mushroom farming partnerships. The experiences may be different and result in dissimilar points. Nevertheless, the present condition of this partnership is mainly the same.

\section{References}

Altalb, A. A. T., Filipek, T., \& Skowron, P. (2015). The Role of Agricultural Extension in the Transfer and Adoption of Agricultural Technologies. Asian Journal of Agriculture and Food Sciences, 03(05), 500-507. Retrieved from https://www.ajouronline.com/index.php/AJAFS/article/viewFile/2962/1680

Anderson, J. R., \& Feder, G. (2004). Agricultural extension: Good intentions and hard realities. World Bank Research Observer, 19(1), 41-60. https://doi.org/10.1093/wbro/lkh013

Ashari. (2009). Peran Perbankan Nasional Dalam Pembiayaan Sektor Pertanian Di Indonesia. Forum Penelitian Agro Ekonomi, 27(1), 13-27. Retrieved from http://ejurnal.litbang.pertanian.go.id/index.php/fae/article/view/3932/3269

Badan Pusat Statistik Kabupaten Cianjur. (2015). Kabupaten Cianjur Dalam Angka 2015 (Cianjur Distric in Numbers 2015). Retrieved from

https://cianjurkab.bps.go.id/new/website/pdf_publikasi/Kabupaten-Cianjur-Dalam-Angka-2015.pdf

Barmon, B. K., Sharmin, I., Abbasi, P. K., \& Mamun, A. (2012). Economics of Mushroom ( Agaricus bisporus ) Production in a Selected Upazila of Bangladesh. The Agriculturalists, 10(November), 77-89. Retrieved from https://www.banglajol.info/index.php/AGRIC/article/view/13144

Beetz, A., \& Greer, L. (1999). Mushroom Cultivation and Marketing, Horticulture Production Guide. Retrieved from https://www.mushroomcompany.com/resources/background/attramushroom.pdf

Bitzer, V., Glasbergen, P., \& Arts, B. (2013). Exploring the potential of intersectoral partnerships to improve the position of farmers in global agrifood chains: Findings from the coffee sector in Peru. Agriculture and Human Values, 30(1), 5-20. Retrieved from http://dx.doi.org/10.1007/s10460-012-9372-z

BPS Kabupaten Cianjur. (2017). Kabupaten Cianjur dalam Angka 2016. Kabupaten Cianjur dalam Angka. Retrieved from https://cianjurkab.bps.go.id/index.php/publikasi/259

Cheung, P. C. (2010). The nutritional and health benefits of mushrooms. Nutrition Bulletin, 35, 292-299. Retrieved from https://doi.org/10.1111/j.1467-3010.2010.01859.x

Dentoni, D., Bitzer, V., \& Pascucci, S. (2016). Cross-Sector Partnerships and the Co-creation of Dynamic Capabilities for Stakeholder Orientation. Journal of Business Ethics, 135(1), 35-53. https://doi.org/10.1007/s10551-015-2728-8

Dirjen Hortikultura Kementerian Pertanian. (2015). Statistik Produksi Hortikultura Tahun 2014. Statistik Produksi Hortikultura Tahun, 2014, 286. Retrieved from http://hortikultura.pertanian.go.id/wp-content/uploads/2016/02/Statistik-Produksi-2014.pdf

Duffy, M. (2000). The internet as a research and dissemination resource. Health Promotion International, 15(4), 349-353. https://doi.org/10.1093/heapro/15.4.349

FAO. (2013). Contract farming for inclusive market access. (C. A. da Silva, And, \& M. Rankin, Eds.). Rome. Retrieved from http://www.fao.org/3/a-i3526e.pdf 
FAO. (2016). Public-private partnerships for agribusiness development: A review of international experiences. (M. Rankin, E. G. Nogales, P. Santacoloma, N. Mhlanga, \& C. Rizzo, Eds.). Retrieved from http://www.fao.org/3/a-i5699e.pdf

Febrianda, R., \& Laili, N. (2016). Social Context Analysis to Developing Oyster Mushroom Business in Palembang City, South Sumatera, Indonesia (unpublished work).

Febrianda, R., \& Tokuda, H. (2017). Strategy and Innovation of Mushroom Business in Rural Area Indonesia: Case Study of a Developed Mushroom Enterprise from Cianjur district, West Java, Indonesia. International Journal of Social Science Studies, 5(6), 21. https://doi.org/10.11114/ijsss.v5i6.2304

Feder, G., Just, R. E., \& Zilberman, D. (1985). Adoption of Agricultural Innovations in Developing Countries: A Survey. Economic Development and Cultural Change, 33(2), 255-298. https://doi.org/10.1086/451461

Feeney, M. J. (2011). Increasing Worldwide Consumption of Mushrooms: The Mushrooms and Health Global Initiative at Work. The International Society for Mushroom Science, (13), 2738-2747. Retrieved from http://epub.cnki.net/grid2008/brief/detailj.aspx?filename=ZNYK201113013\&dbname=CJFQ2011

Kaldis, P., \& Kontogeorgakos, D. (2002). Economic aspects of the emerging Greek mushrooms industry, 60-64. Retrieved from http://newmedit.iamb.it/share/img_new_medit_articoli/212_60kaldis.pdf

Kolk, A., van Tulder, R., \& Kostwinder, E. (2008). Business and partnerships for development. European Management Journal, 26(4), 262-273. Retrieved from https://econpapers.repec.org/RePEc:eee:eurman:v:26:y:2008:i:4:p:262-273

Lahman, O., \& Rinker, D. L. (2002). Mushroom Practices and Production in Latin America: 1994-2002. The International Society for Mushroom Science, 16(1). Retrieved from http://www.isms.biz/florida/volume-16-part-1-article-91/

Lelley, J. (1988). Growing Edible Mushroom - Still a Generally Neglected Opportunity. Gate, 4, 30-34.

Mahajan, V. (1990). Determination of Adopter Categories by Using Innovation Diffusion Models, 37-50. Retrieved from http://ink.library.smu.edu.sg/cgi/viewcontent.cgi?article=5121\&context=lkcsb_research

Marshall, E., Nair, (Tan).N.G. (2009). Make money b y growing mushrooms. Rome: Food and Agriculture Organization (FAO) of The United Nations. Retrieved from http://www.fao.org/3/a-i0522e.pdf

Merriam-webster.com. (n.d.). innovation. Retrieved from https://www.merriam-webster.com/dictionary/innovation

OECD. (2014). Public-Private Partnerships For Agricultural Innovation: Report On The Meeting Of The Food Chain Analysis Network. Paris, France. Retrieved from

https://www.oecd-ilibrary.org/agriculture-and-food/public-private-partnerships-for-agricultural-innovation_5jm55j 9p9rmx-en?crawler=true

Pradhan, L., \& Nayak, M. P. (2014). Issues and Opportunities in Spread of Mushroom Enterprise in Odisha. Proceedings of the 8th International Conference on Mushroom Biology and Mushroom Products, 623-626. Retrieved from http://www.wsmbmp.org/2/90.pdf

Purnaningsih, N. (2006). Inovasi Pola Kemitraan Agribisnis Sayuran di Provinsi Jawa Barat. Bogor Agricultural University. Retrieved from http://repository.ipb.ac.id/handle/123456789/40702

Rogers, E. (2003). Diffusion of Innovations. New York: Free Press (Vol. 5). https://doi.org/10.1016/j.jmig.2007.07.001

Royer, A., Bijman, J., \& Abebe, G. K. (2017). Cooperatives, partnerships and the challenges of quality upgrading: A case study from Ethiopia. Journal of Co-Operative Organization and Management, 5(1), 48-55. https://doi.org/10.1016/j.jcom.2017.04.001

Ton, G., Vellema, W., Desiere, S., Weituschat, S., \& D’Haese, M. (2018). Contract farming for improving smallholder incomes: What can we learn from effectiveness studies? World Development, 104, 46-64. https://doi.org/https://doi.org/10.1016/j.worlddev.2017.11.015

Wayan, N., Rusadi, P., Susrusa, K. B., \& Ap, I. G. S. (2015). Hubungan Antara Jiwa Kewirausahaan dan Manajemen Agribisnis terhadap Keberhasilan Usaha Jamur Tiram di Kota Denpasar Pendahuluan. Jurnal Manajemen Agribisnis, 3(2), 134-146. Retrieved from

https://media.neliti.com/media/publications/26300-ID-hubungan-antara-jiwa-kewirausahaan-dan-manajemen-agrib isnis-terhadap-keberhasila.pdf

Youri, M. R., Tano-Debrah, K., Obodai, M., \& Smith, J. F. (2004). Bioconversion of some agro-processing waste through Pleurotus production. Mushroom Science, 16(Science and Cultivation of Edible and Medicinal Fungi), 
599-609. Retrieved from http://www.isms.biz/florida/volume-16-part-1-article-79/

Zhang, Y., Geng, W., Shen, Y., Wang, Y., \& Dai, Y. C. (2014). Edible mushroom cultivation for food security and rural development in China: Bio-innovation, technological dissemination and marketing. Sustainability (Switzerland), 6(5), 2961-2973. https://doi.org/10.3390/su6052961

\section{Appendix}

Correlation

\begin{tabular}{|c|c|c|c|c|c|c|c|c|}
\hline & & & Groups & Education & KnowledgeSource & DecisionLength & StartingScale & MaximumScale \\
\hline \multirow[t]{18}{*}{$\begin{array}{l}\text { Spearman's } \\
\text { rho }\end{array}$} & \multirow[t]{3}{*}{ Groups } & $\begin{array}{l}\text { Correlation } \\
\text { Coefficient }\end{array}$ & 1.000 & $.462^{*}$ & .274 & & $.630^{* * *}$ & $.426^{*}$ \\
\hline & & $\begin{array}{l}\text { Sig. } \\
\text { tailed })\end{array}$ & & .010 & .143 & .000 & .000 & .019 \\
\hline & & $\mathbf{N}$ & 30 & 30 & 30 & 30 & 30 & 30 \\
\hline & \multirow[t]{3}{*}{ Education } & $\begin{array}{l}\text { Correlation } \\
\text { Coefficient }\end{array}$ & $.462^{*}$ & 1.000 & $.465^{* *}$ & & .273 & .343 \\
\hline & & Sig. (2-tailed) & .010 & . & .010 & .142 & .145 & .064 \\
\hline & & $\mathrm{N}$ & 30 & 30 & 30 & 30 & 30 & 30 \\
\hline & \multirow[t]{3}{*}{ KnowledgeSource } & $\begin{array}{l}\text { Correlation } \\
\text { Coefficient }\end{array}$ & & $.465^{* *}$ & 1.000 & & & \\
\hline & & Sig. (2-tailed) & .143 & .010 & . & .235 & .812 & .880 \\
\hline & & $\mathrm{N}$ & 30 & 30 & 30 & 30 & 30 & 30 \\
\hline & \multirow[t]{3}{*}{ DecisionLength } & $\begin{array}{l}\text { Correlation } \\
\text { Coefficient }\end{array}$ & $-.618^{* * *}$ & -.275 & & 1.000 & -.333 & -.316 \\
\hline & & Sig. (2-tailed) & .000 & .142 & .235 & & .073 & .089 \\
\hline & & $\mathrm{N}$ & 30 & 30 & 30 & 30 & 30 & 30 \\
\hline & \multirow[t]{3}{*}{ StartingScale } & $\begin{array}{l}\text { Correlation } \\
\text { Coefficient }\end{array}$ & $.630^{* *}$ & .273 & .045 & -.333 & 1.000 & $.726^{* *}$ \\
\hline & & Sig. (2-tailed) & .000 & .145 & .812 & .073 & . & .000 \\
\hline & & $\mathrm{N}$ & 30 & 30 & 30 & 30 & 30 & 30 \\
\hline & \multirow[t]{3}{*}{ MaximumScale } & $\begin{array}{l}\text { Correlation } \\
\text { Coefficient }\end{array}$ & $.426^{*}$ & .343 & .029 & -.316 & $.726^{* * *}$ & 1.000 \\
\hline & & Sig. (2-tailed) & .019 & .064 & .880 & .089 & .000 & J. \\
\hline & & $\mathrm{N}$ & 30 & 30 & 30 & 30 & 30 & 30 \\
\hline
\end{tabular}

*. Correlation is significant at the 0.05 level (2-tailed).

**. Correlation is significant at the 0.01 level (2-tailed).

\section{Copyrights}

Copyright for this article is retained by the author(s), with first publication rights granted to the journal.

This is an open-access article distributed under the terms and conditions of the Creative Commons Attribution license which permits unrestricted use, distribution, and reproduction in any medium, provided the original work is properly cited. 